\title{
Spirituality in the perspective of foundational theology
}

\begin{tabular}{|c|c|}
\hline \multicolumn{2}{|l|}{ Author: } \\
\hline \multicolumn{2}{|c|}{$\begin{array}{l}\text { Affiliations: } \\
{ }^{1} \text { Department of Religion } \\
\text { and Social Theory, Radboud } \\
\text { Universiteit, The Netherlands }\end{array}$} \\
\hline \multicolumn{2}{|c|}{$\begin{array}{l}{ }^{2} \text { Department of Systematic } \\
\text { Theology, University of } \\
\text { Pretoria, South Africa }\end{array}$} \\
\hline \multicolumn{2}{|c|}{$\begin{array}{l}\text { Note: } \\
\text { Prof. Dr Toine van den } \\
\text { Hoogen is a research fellow } \\
\text { of Prof. Dr Johan Buitendag, } \\
\text { Dean of the Faculty of } \\
\text { Theology of the University } \\
\text { of Pretoria. The article often } \\
\text { refers to the text of Professor } \\
\text { Van den Hoogen's book, A } \\
\text { taste of God: On spirituality } \\
\text { and reframing foundational } \\
\text { theology, LIT Verlag, } \\
\text { Münster, 2011a. }\end{array}$} \\
\hline \multicolumn{2}{|c|}{$\begin{array}{l}\text { Correspondence to: } \\
\text { Toine van den Hoogen }\end{array}$} \\
\hline \multicolumn{2}{|c|}{$\begin{array}{l}\text { Email: } \\
\text { t.vdhoogen@gmail.com }\end{array}$} \\
\hline \multicolumn{2}{|c|}{$\begin{array}{l}\text { Postal address: } \\
\text { Radboud Universiteit, } \\
\text { Erasmusplein 1, Nijmegen, } \\
\text { The Netherlands }\end{array}$} \\
\hline \multicolumn{2}{|c|}{$\begin{array}{l}\text { Received: } 23 \text { Oct. } 2013 \\
\text { Accepted: } 08 \text { Apr. } 2014 \\
\text { Published: } 14 \text { Aug. } 2014\end{array}$} \\
\hline \multicolumn{2}{|c|}{$\begin{array}{l}\text { How to cite this article: } \\
\text { Van den Hoogen, T., } \\
\text { 2014, 'Spirituality in the } \\
\text { perspective of foundational } \\
\text { theology', HTS Teologiese } \\
\text { Studies/Theological Studies } \\
70(1) \text {, Art. \#2085, } 6 \text { pages. } \\
\text { http://dx.doi.org/10.4102/ } \\
\text { hts.v70i1.2085 }\end{array}$} \\
\hline \multicolumn{2}{|c|}{$\begin{array}{l}\text { Copyright: } \\
\text { C 2014. The Authors. } \\
\text { Licensee: AOSIS } \\
\text { OpenJournals. This work } \\
\text { is licensed under the } \\
\text { Creative Commons } \\
\text { Attribution License. }\end{array}$} \\
\hline \multirow{2}{*}{ 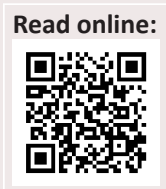 } & \\
\hline & $\begin{array}{l}\text { Scan this QR } \\
\text { code with your } \\
\text { smart phone or } \\
\text { mobile device } \\
\text { to read online. }\end{array}$ \\
\hline
\end{tabular}

Systematic theology, especially the so-called foundational theology, has a strong connection with traditions of philosophy, at least in Western thinking. From the 20th century onward, systematic theology was often focussed on forms of transcendental philosophy. This article argues why this kind of research has to be deepened by research into different forms of spirituality. Research into 'lived spirituality' offers new pathways for foundational theology and makes the need to develop a renewed approach to foundational theology all the more urgent.

\section{Introduction}

Once, the Catalan artist, Joan Miró (1893-1983), travelled by air to the United States of America (USA). Nowadays, travelling for 10 hours at an altitude of $12 \mathrm{~km}$ and a groundspeed of $900 \mathrm{~km}$ per hour through the dark of night is an experience known to far more people than was the case during Miró's days. However, the impression it made on him is still very recognisable. In Miró's oeuvre, it found expression in his painting called Une étoile caresse le sein d'une négresse (1938) or 'a star caresses the breast of a Negress'. Miró was often preoccupied with the darkness of night in his paintings; for him, it is an artistic portrayal of spiritual freedom with all the ambiguity and contrasts it entails. Miró had a love for the unattainable.

This ambiguous love for the unattainable and the artistic expressions thereof are my points of departure in looking for new approaches for systematic theology. Systematic theology is often practiced by using rather different loci theologici as point of departure (cf. Melchior Cano, De Locis Theologicis, Salamanca 1562). Doctrines of the church and scriptural texts or philosophical paradigms are more common in this field. Artistic expressions of the ambiguous love for the unattainable have not attracted the attention of theologians that much.

Commenting on Miró's work, Penrose (1976) writes that Miró's 'night' is a metaphor for our daylight reality:

Miró's world is one in which birds and shooting stars encircle a woman in the dark of night; in which dewdrops fall from a bird's wing. In this world, a ladder of escape reaches into the depths of night and a woman with tangled hair welcomes the rising moon. We witness the passage of the divine bird and a dog barking at the moon. (pp. 40-41)

According to Penrose (1976:40-41), Miró's world has 'a nocturnal indifference to the recognised magnitude of all things'.

Looking for a point of departure for systematic theology, this article argues that this experience, the experience of 'a nocturnal indifference to the recognized magnitude of all things' (Penrose 1976:40-41)is a valuable locus theologicus for us, living in the (South) African and Western parts of the world during the first decade of the 21st century.

\section{On spirituality}

Many differences characterise those times when Cano wrote about loci theologici and our times. One of the big differences is our historical (geschichtlicher) awareness of human existence. This historical awareness means that our daily experiences about living and survival and desired optimal lives are marked by heuristics, and by all kinds of hermeneutical strategies with which we denote what makes our daily lives relevant. Perhaps human beings have never had direct access to their reality. Our access to reality is mediated by hermeneutical strategies. Thiselton (2009) states that:

Hermeneutics does not encourage the production of tight, brittle, fully formed systems of thought that are 'closed' against modification or further development. The horizons of interpreters in hermeneutical inquiry are always moving and expanding, and always subject to fresh appraisal. (p. 15) 
Thiselton (2009) goes on to say that this process of reinterpretation constitutes a 'nest':

What we believe, has not the form of a rigid system but is a flexible whole; we create it, form it bit by bit, some things stand unshakeably fast, and others are more or less liable to shift. (p. 15)

This means that 'the recognised magnitude of all things' (Penrose 1976:40-41) is an awareness of reality that has the character of a 'nest' - a flexible whole. And we perceive it with a kind of indifference towards it, attracted by its magic forms and distancing ourselves, as we cannot grasp it in its endless darkness. In my view, Penrose's words refer to what might be called a spiritual experience, which many of us are familiar with in our day-to-day reality.

To begin with, I would approach spirituality in a secular way (Van den Hoogen 2011a), an approach that can be recognised in religious and non-religious idioms and forms, as, for example, in Miró's painting. The secular approach of spirituality requires, first of all, a phenomenological grasp of it. Spirituality is about an experience and about an attitude; it is about a perception and about a memory. Spirituality is a consciousness that ties people down, often compelling them to choose. In a secular perspective, spirituality harbours the reality of the unexpected, the instantaneously appearing connection with the mystery of all reality, experienced as freedom and emancipation. This connection with all reality can be a solitary dream and a celebration of everything for everybody, something that happens between dusk and daybreak. But it can be as banal as slovenliness, or trudging across a ploughed.

From a phenomenological grasp, spirituality is a word that refers to a consciousness of the marvelous and banal transformation of all life (cf. Waaijman 2000:301-589). That is why Miró's painting can be understood as a 'nest' - a nest of secular spiritual experience. Miró's painting shows an enchanted ladder into the infinite depth of all reality. Every element of this painting has a role or function in this 'nest', like the dog's baying at the moon, like the dewdrop falling from a bird's wing and the star caressing a black woman's breast (Penrose 1976:40-41).

A spiritual experience can be interpreted from a religious perspective as well. A religious point of view does not add 'something' to the compelling, free, banal or enchanted characteristics of our human experiences. A religious perspective pays attention to and makes aware of the glow and splendour as well as the dullness of the idioms and rituals and imagery as to be found in religious traditions. Religious traditions function as horizons within which spiritual experiences become embedded in 'a system of symbols that give them powerful, pervasive and longlasting persistence, making it possible to relate them to the general order of existence and clothe them in an aura of factuality and uniqueness'. I am using here literally the elements of the famous definition of Clifford Geertz's (Capps 1995:181) thick description of religion in his classic work, The interpretation of culture (1973). Religious traditions offer an interpretive framework of spiritual experiences. They offer interpretations of the 'nest' (Thiselton 2009:15) that mark a spiritual experience that partially makes them unshakably fast and partially liable to shift.

When we make theological reflections - when we 'do' theology - we take a religious tradition as our point of reference. The relevance and identity of a specific religious tradition (e.g. Christian faith) is at stake when we 'do' theology. I will explain further why 'doing' theology is considered often in our Christian tradition as a reflection on merely the doctrinal dimensions of our Christian faith. This article wants to argue why this focus on doctrinal dimensions should be enriched and deepened by considering spiritual experiences being the (socially and personally) vivid dimension of the Christian tradition.

This article argues that secularly and religiously framed 'nests' of spiritual experiences are important to understand the very reasons of the doctrinal expressions of Christian faith and to understand the expressiveness of this Christian faith in our cultures and societies. I am following here some important points of view of Schillebeeckx (1989), but many others have stressed this as well. When dogmatics tries to understand its sources and its actual relevance, we have to re-interpret the Christian doctrines as expressions of the experiential source of Christian faith. It is the experiential source of religion that appears as the 'mediated immediacy' (Schillebeeckx 1989:34-47) of a specific, historical and - at the same time - unique reality. Schillebeeckx used to state that religion has its centre in a specific and personal experience of God's presence in our history (the immediate dimension of religion) and that human beings only have access to this presence with the help of human language (the mediated dimension of religion). According to those who share their lives in a religious tradition and community, this specific, historical and unique reality touches them and they taste it. Therefore, doctrinal dimensions should be enriched and deepened by considering spiritual experiences.

Being touched by this reality - often named God - the participants in a religious tradition look for possibilities of the original and ultimate survival of humankind in this world; they discover the dynamics of their historical state and existence in this world, and they design and imagine the desired optimal life of humankind and the world (cf. Van den Hoogen 2011a:passim).

As the spiritual experiences are the mediated immediacy of a religious tradition, systematic-theological doctrines have their vivid sources in forms of spirituality; for example, quite a few so-called high Christological definitions have their sources in the spirituality of the desert monks in 3rd and 4th century BC. Originally, these doctrines express in different ways how people expect to be touched by 'God' and hope to be touching and tasting 'God'. Spirituality offers a theatre of knowledge and truth (Bocken 2008) and a tradition of qualified messages that asks for hermeneutics of 
the testimonies of divine revelation in contingent historical realities (Verweyen 1998:186-189).

Doctrines about creation and eschatology should - in my opinion - be referred to as being about original and ultimate survival; doctrines about the history of salvation, sin and grace should be referred to as being about the historical state and existence; and doctrines about apocalypse should be as being about the referred to the desired optimal life. The hermeneutical key to these kinds of doctrines can be found in nests of spiritual experiences. Research on these doctrines that are focussed on these experiences as its interpretative key will enliven and renew traditional dogmatics. Theological research has to expect a new dynamic outlook where it can highlight forms of spirituality in order to understand and explain its main topics. Research in spirituality is not a pious adaptation of doctrines but may be expected to be a renewal of the core business of dogmatics.

\section{Spirituality and foundational theology}

Why did we 'forget' these sources of the doctrinal traditions of Christian faith? Why did the gap between spirituality and dogmatics grow deeper and deeper? This section will give a rough sketch of some historical developments in dogmatics which are helpful to understand this.

Foundational theology (often called Fundamentaltheologie in German Catholic circles, or Théologie fondamentale in French Catholic traditions, or Philosophischer Theologie in Protestant German circles) had various roles from the 16th century onward. The American theologian, Francis Schüssler Fiorenza (1984:265-284), summarised its successive roles as follows:

- 16 th and 17th centuries: retrieval of the basic teachings of Christianity

- 18th and 19th century: apologetic defence of Christianity

- 20th century: transcendental foundation of Christian revelation and Christian theology.

Schüssler Fiorenza (1984:265-284) created the category 'foundational theology' as he argued that during the previous centuries the classic name, theologia fundamentalis, was increasingly positioned towards dogmatic theology in an external and strongly defensive relationship. The core of Christian faith, its dogmas and doctrines, was supposed to need external walls that surrounded it. This theologia fundamentalis was clothed in an epistemology that was marked by a rigid deductive methodology. Marie-Dominique Chenu (1895-1990), a French theologian and historian, used to repeat (in personal meetings I had with Chenu) that one of his masters, Réginald Marie Garrigou-Lagrange (1877-1964), totally separated spirituality and dogmatics; spirituality is about a personal realisation of private faith. In GarrigouLagrange's view (1919), dogmatics is about a belief system marked by an ahistorical truth claim and is supposed to be organised from the most general rational concepts about
'God' and 'Revelation' to the most specific contents of the Christian Creed; according to Garrigou-Lagrange, as Chenu often used to recall, 'l'Incarnation ce n'est qu'un fait'. As theology has to develop concepts with a universal content, the Incarnation is not that important for theological thinking at all (Garrigou-Lagrange 1919).

This ahistorical truth claim is important to understand why a gap between dogmatics and spirituality grow deeper and deeper. From 1940 to 1950 onward, Catholic theology reframed this ahistorical truth claim. Influences of exegetical and historical research in Scripture and tradition have unavoidably influenced this process of reframing. However, an ongoing interest in Reformed theology has had its consequences as well.

As a consequence of these influences, the strongly deductive approach of theological research rapidly lost its normative character. In the Catholic Church from 1960 to 1970, a widespread hermeneutical stance became a main characteristic of dogmatics and of other theological disciplines; for example, theological ethics, Old Testament and New Testament exegesis, practical theology, and liturgy. The same applies to many theologians in churches associated with the World Council of Churches.

Schüssler Fiorenza made an important contribution to the deductive approach by his reconstruction of the history of foundational theology. Referring to theologians like Rahner, Brunner, Bultmann and philosophers like Dilthey, Gadamer and Heidegger, he stressed that any truth claim in dogmatics is founded on an interpretative approach of human experience, as all human experiences have a historic (geschichtlicher) character (Schüssler Fiorenza 1984:passim). Influenced by these theologians and philosophers, the separation between concepts and experiences was reframed into a dialectical relationship. This dialectical relationship became a landmark of fundamental theology as well as dogmatics; for example, historical and exegetical materials and the interpretations of it in the field of Christology became part of (different) conceptual outlines of dogmatic approaches of Christology. As a consequence, 20th century dogmatics was no longer separated from theologia fundamentalis. According to Schüssler-Fiorenza, dogmatics and foundational theology have to be distinguished by different roles. However, their content always grapples with the ways in which human beings dialogically reflect on the foundations of their existence and its relationships with God, Jesus and the church (Schüssler Fiorenza 1984:passim). These words can only be understood as they are mediated by our human experiences. This leaves no room for GarrigouLagrange's ideas anymore!

As foundational theology has redefined itself in research about a transcendental foundation of Christian revelation and theology, theologians like Brunner and Rahner have always been convinced that the historical character of human experience is universal. Johan-Baptist Metz stressed therefore that the truth claim of dogmatics has always been embedded 
in, as he has put it, modes of thinking (Metz 1962:10-30). Although our experiences have a historical character, they are embedded in the ways in which we cognitively relate ourselves to the world. A horizon of thinking always encompasses a particular relationship to reality. Religious and non-religious dimensions of our relationship to reality include an understanding of being (Seinsverständnis) as its horizon (Metz 1962:10-30). For many centuries, Western thought about understanding of being was governed by a cosmocentric orientation. Later, it made way for an anthropocentric horizon. Metz (1962) cites Thomas Aquinas as a clear example of this shift.

The awareness that modes of thinking play an important role in theological research has marked foundational theology in the 20th century. This is the decisive reason why foundational theology has developed as a transcendental foundation of Christian revelation and of Christian theology during this era. Dogmatics and foundational theology inquire into conceptualisations of revelation and God by asking how these conceptualisations refer to the historical character of human experience. This kind of research wants to understand how this history (Geschichte) is embedded in modes of thinking, thus in cognitive expressions of our understanding of being.

Ideas about the embeddedness of historical experiences in an understanding of being have had an important influence on conceptions of the task theologians apply by thinking about revelation and God; nevertheless, new questions have risen as well. Foundational theology, as it is elaborated in the wake of a transcendental foundation of Christian revelation and Christian theology is increasingly being criticised by very different theological scholars, as this transcendental mode of thinking hardly pays attention to the pluralist and conflicting contexts of so many human experiences and the consequences thereof for theological research. From 1976 onward, Metz himself has elaborated a 'political theology' (Metz 1977) and, later on, has written essays on biographical theology. Today, at the beginning of the 21st century, it is clear that the histories of self-emancipation and oppression of various Christian communities worldwide have become the context of many practical hermeneutic variants of theology, which often develop in conflict with each other. One of these practical hermeneutic approaches of research in theology is the so-called 'public theology'. The cardinal question in a practical hermeneutic theology is how human life should be interpreted coram Deo in the historical vicissitudes and conflicts in which particular actors enact their histories, that is to say, as the scene and history of God's presence. The next sections will clarify why this is where spirituality features and enters the field of foundational theology.

\section{Life-world rationality}

The developments in Metz's approaches of doing systematic theology give an example that another type of rationality is important if systematic theology - and foundational theology as a part of it - would really take their point of departure from today's spiritual experiences, both non-religious and religious.
Theologians have to become aware that conflicting modes of contextual embeddedness require another type of rationality that does not reduce the vicissitudes and conflicts in our cultural and social worlds to a claim of universality. Theology needs to develop a justification of faith based on the question of how the human subject is instantiated in these conflicting contexts. Systematic theology should develop forms of communicative reasoning that explains and interprets how participants in a concrete life-world give a communal, meaningful account of and provide a foundation for the shape imparted to that life-world. Only then, the 'nest'-character (Thiselton 2009:15) of this life-world will be taken into account seriously. The next paragraph will argue that the anticipation of meaning within the framework of the contingence of all reality is the horizon in which research in a societal context can look for possible avenues for dialogue between profane and religious themes of finding meaning. It is for this reason that this article starts with a reference to the work of Miró. The so-called 'nocturnal indifference to the recognised magnitude of all things' (Penrose 1976:40-41) is such a nest and opens possibilities for this dialogue. In such contexts, the human subject becomes instantiated.

The Flemish Freibourg-based theologian, Guido Vergauwen (2002:101), has termed this kind of rationality 'life-world rationality'. The phenomenological concept, 'life-world', refers to the interrelational structure of sense-giving, in which discovering meaning refers to my personal commitment to my world as well as to possible clues in my world. This concept is a useful one with which one can clarify how foundational theology should deal with the theme of spirituality, namely by researching life-world rationality. Vergauwen (2002) outlines three themes for such research:

- Is there a genuine reciprocity between forms of profane meaning and forms of religious meaning in theological research on spirituality?

- Is theological research (on spirituality) based on the premise that meaning is anticipated in a framework of the contingence of all reality?

- Can human autonomy in its own right be recognised and acknowledged as a locus theologicus?

\section{Lived spirituality: Examples of research}

There is an impressive tradition in the study of spirituality that focusses on linguistic articulations of spirituality (e.g. in the work of Ruusbroec, Theresa of Avila and Ignatius of Loyola). Research into such authors mostly examines their texts. As linguistic theories and methods that take account of the historical contexts of texts have been developed, textual analysis could result in a multilayered concept of human experience being the framework within which spirituality is always embedded; for example, Mommaers and Van Bragt (1995) show that a phenomenological approach can greatly enrich the study of spirituality. De Certeau (1982) cites fine examples of how contemporary theories on historical research into spirituality produce similar results. 
Additional to a phenomenological and historical approach to spirituality, others (amongst them the Nijmegen-based Titus Brandsma Institute) pay attention to so-called lived spirituality. Lived spirituality examines human behavioural phenomena in both historical and present-day horizons. This is a new dimension of the study of spirituality. When human behaviour is taken as a framework of spirituality, different research methodologies and methods are needed. Lived spirituality, first of all, refers to how people as actors in a specific social and cultural context perform all kinds of acts to realise their perceived values and transform themselves in ways that they expect to satisfy their longing. Insofar as human behaviour is considered to be the 'place', 'stage' or 'forum' where this acting, longing person can be observed, the study of lived spirituality faces new questions about its methodology and methods. Research in the field of spirituality has to comply with socio-scientific theories and methods. A wide variety of cultural expressions and social behaviour can be analysed in order to reconstruct forms of lived spirituality including:

- culture (e.g. clothing, food, architecture and the human body)

- psychosomatic health (e.g. ideas, practices and communities)

- economy (e.g. corporate social responsibility and greed)

- ecology (e.g. how to deal with environmental issues)

- justice and peace

- sport.

The reconstruction of forms of lived spirituality opens a huge and complex field of research, wherein an irreducible heterogeneity of phenomena of lived spirituality can be observed and analysed. Theological research into these phenomena could be focussed on its life-world rationality with the help of the three themes developed by Vergauwen (2002).

An example of research into lived spirituality is that of Baarda (2007), whose master's thesis looks at 'walking the labyrinth'. Empirical research was conducted into contemporary practices of walking the labyrinth. This ancient symbol and rite has in our day again become the focus of attention, as people use this ritual to give depth and meaning to their lives. The labyrinth can be described as a nonstop, meandering path that leads to a centre. A labyrinthic spirituality with liminal, liminoid and playful qualities appears to be a phenomenon of present-day lived spirituality.

Many more similar groups and situations have to be studied to permit comparison and avoid the risk of essentialism. Yet, the example clearly suggests that in everyday lives, individuals look for a position 'in between', between the social and transcendental dimension of their lives. It shows how they oscillate between these poles in a paradoxical way and how they form hybrids of traditional religious practices and mundane circumstances. This makes clear that actual constructions of faith do not have a transcendental centre any more - there is no centre. There is only religiosity 'in between'. Baarda has been sensitive to any attempts by her respondents to present their ideas about 'totality' in ideological terms. However, her conclusion is still justified; walking the labyrinth really is a case of finding one's way to the centre, as the thesis is entitled.

Baarda submitted her master's thesis to the faculty of religious studies. Had she submitted it to the theological faculty and elaborated her research from a theological perspective (e.g. by comparing her data with exegetical research about 'following Jesus'), the three themes of Vergauwen (2002) would apply. If we were to make a theological interpretation of this labyrinthic spirituality (i.e. if this labyrinthic spirituality could be construed as a modern way of following Jesus), we should avoid adding 'some theology' to the profane meaning of walking the labyrinth; we should be cautious not to reduce the contingency of this following of Jesus, and we should acknowledge that metanoia can be understood as an act of an autonomous actor. Thus, the labyrinthic spirituality should not only be reconstructed as a modern application of 'following Jesus'. The exegetical and theological data should be re-interpreted by this labyrinthic spirituality as well.

\section{Conclusion \\ Points of departure of systematic theology}

The introduction of this article stated that the experience of 'a nocturnal indifference to the recognised magnitude of all things' (Penrose 1976:40-41) is a valuable locus theologicus. These words can be understood as an expression of a nonreligious spirituality. If these words were to be taken into account in a theological argument, three steps are important (Van den Hoogen 2011b:25-27).

The first line of theological interpretation requires that a theologian deepens his or her knowledge about the oeuvre of this artist; in other words, the history, influences and artistic background of it. This first line is called the context of a phenomenon. This background does not consist of an external set of data only. This nocturnal flight and its artistic impression refer to a sociocultural phenomenon that did not exist in, say, the times of Rembrandt. Historical, sociological and psychological knowledge, in this case art history as well, ought to be inserted in this first line of theological interpretation. They explain dimensions of the heart of the matter without which the phenomenon (the spiritual experience) cannot be interpreted.

A second line of research, called the configuration of a phenomenon, focusses on which specific ways the background data is configured to express 'the nocturnal indifference to the recognised magnitude of all things' (Penrose 1976:40-41). Penrose's comment is actually an analysis of this configuration. This configuration can only be explained by a thorough and critical knowledge of Miró's life and work. Penrose's comment is a 'nest' as his interpretation of Miró's painting tries 'to keep intact' the picture as a whole that sheds light on the parts whilst he critically approaches 
the painting (Thiselton 2009:15-16). The interpretation of the actual togetherness of the different background data permits transference from a social to a cosmic reality (Devisch \& De Broeck 1989). All the elements together in this work of Miró frame an awareness of transcendence that encompasses the earthly realities in a cosmic horizon.

The third line of research is into the dynamism of this sociocultural phenomenon. Here, the interpretation is steered by the question of how this specific artistic expression of a flight performs a way to the unattainable. All background elements and their configuration, being a 'nest', express a longing for the ultimate, for God as one sees it (Schneiders 1990:15-37). This dynamism can only be understood if a theologian looks for a spiritual way that is expressed in this phenomenon. Configurations of this longing for God can be reconstructed from the personal or social perspective of an individual who tries to signify his or her longing for God.

This longing for God is not necessarily present in this phenomenon. We are not forced to recognise the longing for God or to consider this perspective being rationally undeniable. But if we do theology, we try to refer this 'nocturnal indifference to the recognised magnitude of all things' (Penrose 1976:40-41) to the tradition of faith we share in our Christian church-community. We try to argue that this 'nocturnal indifference to the recognised magnitude of all things' gives a clue of the ways how our God is moving towards us. In so doing, Miró's artistic portrayal of spiritual freedom can be interpreted theologically. The truth claim of this interpretation implies that it makes sense to understand this portrayal of spiritual freedom as a 'nest'. Our communal belief (shared in church) is, once transferred to theological research (disputed within academia), a continuing hypothesis, always moving and expanding and always subject to fresh appraisal.

\section{Acknowledgements Competing interests}

The author declares that he has no financial or personal relationship(s) that may have inappropriately influenced him in writing this article.

\section{References}

Baarda, M., 2007, 'Op weg naar het midden: Kwalitatief onderzoek naar de spirituele praktijk van het labyrint lopen', MA thesis, Department of Theology and Religious Studies, University of Nijmegen.

Bocken, I., 2008, 'Theatre of knowledge and truth: Encyclopedic thinking, system theory and spirituality', in H. Blommestijn (eds.), Seeing the seeker. Explorations in the Discipline of Spirituality. A Festschrift for Kees Waaijman on the occasion of his 65th birthday, pp. 49-75, Peeters, Leuven.

Capps, W.H., 1995, Religious studies: The making of a discipline, Fortress Press, Minneapolis.

De Certeau, M., 1982, La fable mystique: Vol. 1, XVle-XVIle Siècle, Editions Gallimard, Paris.

Devisch, R. \& De Broeck, F., 1989, 'Semantische praxeologie van de kulturele lichaamssymboliek', Antropologische Verkenningen 8(2), 29-39.

Garrigou-Lagrange, R., 1919, Dieu, son existence et sa nature. Solution thomiste des antinomies agnostiques, 3rd edn., Beauchesne, Paris.

Van den Hoogen, T., 2011a, A taste of God: On spirituality and reframing foundational theology, LIT Verlag, Münster.

Van den Hoogen, T., 2011b, 'Elements of a theory about lived spirituality', in E. Hense \& Fr. Maas (eds.), Towards a theory of spirituality, pp. 15-27, Peeters, Leuven.

Metz, J.-B. 1962, Christliche antropozentrik: Über die denkform des Thomas von Aquin, Kösel, München.

Metz, J.-B. 1977, Glaube in geschichte und gesellschaft, Matthias Grünewald Verlag, Mainz.

Mommaers, P. \& Van Bragt, J., 1995, Mysticism: Buddhist and Christian encounters with Jan van Ruusbroec, Crossroad, New York.

Penrose, R., 1976, 'The magic of night', in San Lazarro, G.di (ed.), Hommage to Joan Miró, pp. 40-41, Ebeling, London.

Schillebeeckx, E., 1989, Mensen als verhaal van God, Nelissen, Baarn.

Schneiders, S., 1990, 'Spirituality in the academy', in B. Hanson (ed.), Modern Christian spirituality, pp. 15-37, Atlanta.

Schüssler Fiorenza, F., 1984, Foundational theology: Jesus and the church, Crossroad, New York.

Thiselton, A.C., 2009, Hermeneutics: An introduction, William B. Eerdmans Publishing Company, Grand Rapids.

Vergauwen, G., 2002, 'Zustimmung und stimmigkeit: Die rationalität theologischer rede', in P. Neuner (Hrsg.), Glaubenswissenschaft? Theologie im spanningsfeld von glaube, rationalität und öffentlichkeit, pp. 99-124, Herder, Freiburg.

Verweyen, H.-J., 1998, 'Theologische hermeneutik heute', in Kl. Müller (Hrsg.), Fundamentaltheologie. Fluchtlinien und gegenwärtige herausforderungen, pp. 177192, Friedrich Pustet Verlag, Regensburg.

Waaijman, K., 2000, Spiritualiteit: Vormen, grondslagen, methoden, Carmelitana/Kok, Gent/Kampen. 